known. However, both the real and perceived predictive values could have important impacts on the use of TB resources and on the failure to provide appropriate care.

Finally, this study was conducted at a single institution in New York City serving a population in which TB, as well as other comorbidities such as HIV infection, are common. Therefore, our findings may not be generalizable to other institutions, especially those serving populations with a lower prevalence of TB. Whereas ratios similar to ours of total patients isolated to cases of TB isolated have been reported from an institution in Atlanta, Georgia, ${ }^{3}$ another study from Iowa ${ }^{9}$ noted a ratio of 92:1. This suggests that, given clinicians' adoption of a conservative strategy and a high index of suspicion for TB, the lower the prevalence of disease among a hospital's admissions, the greater the proportion of TB-specific resources that are consumed by patients who ultimately do not prove to have TB.

In spite of these limitations, we believe our data provide an informative accounting of the utilization of TBspecific resources and a more relevant basis upon which to plan future resource allocations for managing confirmed and suspected disease, as opposed to data that are generated by identifying only those patients with a confirmed diagnosis. In addition, our results indicate that prolonged diagnostic uncertainty, misclassification of cases due to AFBsmear results, and conservative management have a profound impact on use of TB resources. Finally, our findings raise the question as to whether more accurate and rapidly available diagnostic tests, such as nucleic acid amplification assays, could reduce use of resources in patients who do not have TB.

\section{REFERENCES}

1. Cantwell MF, Snider DE, Cauthen GM, Onorato IM. Epidemiology of tuberculosis in the United States, 1985 through 1992. JAMA 1994;272:535-539.

2. Centers for Disease Control and Prevention. Tuberculosis morbidityUnited States, 1995. MMWR 1996;45:365-370.

3. Blumberg HM, Watkins DL, Berschling JD, Antle A, Moore P, White N, et al. Preventing the nosocomial transmission of tuberculosis. Ann Intern Med 1995;122:658-663.

4. Stroud LA, Tokars JI, Grieco MH, Crawford JT, Culver DH, Edlin BR, et al. Evaluation of infection control measures in preventing the nosocomial transmission of multidrug-resistant Mycobacterium tuberculosis in a New York City hospital. Infect Control Hosp Epidemiol 1995;16:141-147.

5. Centers for Disease Control and Prevention. Guidelines for preventing the transmission of tuberculosis in health care settings, with special focus on HIV-related issues. MMWR 1990;39(RR-17):20.

6. Brown RE, Miller B, Taylor WR, Palmer C, Bosco L, Nicola RM, et al. Health-care expenditures for tuberculosis in the United States. Arch Intern Med 1995;155:1595-1600.

7. Arno PS, Murray CJL, Bonuck KA, Alcabes P. The economic impact of tuberculosis in hospitals in New York City: a preliminary analysis. Journal of Law, Medicine \& Ethics 1993;21(3-4):317-323.

8. Shulkin DJ, Brennan PJ. The cost of caring for patients with tuberculosis: planning for a disease on the rise. Am J Infect Control 1995;23:1-4.

9. Scott B, Schmid M, Nettleman MD. Early identification and isolation of inpatients at high risk for tuberculosis. Arch Intern Med 1994;154:326330 .

10. Greenberg SD, Frager D, Suster B, Walker S, Stavropoulos C, Rothpearl A. Active pulmonary tuberculosis in patients with AIDS: spectrum of radiographic findings (including a normal appearance). Radiology 1994:193:115-119.

11. Shinnick TM, Good RC. Diagnostic mycobacteriology laboratory practices. Clin Infect Dis 1995;21:291-299.

12. Bureau of Tuberculosis Control. Tuberculosis in New York City, 1994. Information Summary. New York, NY: New York City Department of Health; 1995.

13. Centers for Disease Control and Prevention. Reported tuberculosis in the United States, 1993. Atlanta GA: US Department of Health and Human Services, Public Health Service, CDC; 1994.

14. Zar JH. 2nd ed. Biostatistical Analysis. Englewood Cliffs, NJ: Prentice Hall; 1984.

15. Hosmer DW, Lemeshow S. Applied Logistic Regression. New York, NY: John Wiley \& Sons, Inc., 1989.

16. Rawlings JO. Applied Regression Analysis: A Research Tool. Pacific Grove, CA: Wadsworth \& Brooks/Cole Advanced Books \& Software; 1988.

17. Yajko DM, Madej JJ, Ng VL, Hadley WK. Temporal changes in the positive predictive value of the acid fast (AFB) smear for tuberculosis: impact on the utility of nucleic acid amplification tests. 36th ICAAC. New Orleans, LA; September 1996. Abstract D058.

\title{
Global Problem of Drug-Resistant Mycobacterium tuberculosis
}

\section{Gina Pugliese, RN, MS Martin S. Favero, PhD}

Scientists participating in the Global Tuberculosis Program, World Health Organization (WHO), Geneva, recently reported the prevalence of Mycobacterium tuberculosis resistance to four firstline drugs in 35 countries participating in the WHO-International Union against Tuberculosis and Lung Disease Global Project on Anti-Tuberculosis Drug Resistance Surveillance between 1994 and 1997.

The study included a review of data from cross-sectional surveys and surveillance reports. Participating countries followed guidelines to ensure the use of representative samples, accurate histories of treatment, standardized laboratory meth- ods, and common definitions. A network of reference laboratories provided quality assurance. The median number of patients studied in each country or region was 555 (range, 59-14,344).

Among patients with no prior treatment, a median of $9.9 \%$ of $M$ tuberculosis strains were resistant to at least one drug (range, 2\%-41\%); resistance to isoniazid $(7.3 \%)$ or streptomycin $(6.5 \%)$ was more common than resistance to rifampin $(1.8 \%)$ or ethambutol (1.0\%). The prevalence of primary multidrug resistance was $1.4 \%$ (range, 0\%-14.4\%). Among patients with histories of treatment for 1 month or less, the prevalence of resistance to any of the four drugs was $36.0 \%$ (range, $5.3 \%-100 \%$ ), and the prevalence of multidrug resistance was 13\% (range, 0\%-54\%). The overall prevalences were $12.6 \%$ for single-drug resistance (range, 2.3\%-42.4\%) and 2.2\% for multidrug resistance (range, 0\%-22.1\%).

Particularly high prevalences of multidrug resistance were found in the former Soviet Union, Asia, the Dominican Republic, and Argentina.

Resistance to antituberculosis drugs was found in all 35 countries and regions surveyed, suggesting that it is a global problem.

FROM: Pablos-Mendez A, Raviglione MC, Laszlo A, Binkin N, Rieder HL, Bustreo $\mathrm{F}$, et al. Global surveillance for antituberculosis-drug resistance, 1994-1997. World Health Organization-International Union Against Tuberculosis and Lung Disease Working Group on Anti-Tuberculosis Drug Resistance Surveillance. $N$ Engl J Med 1998;338:1641-1649. 